\title{
Key sustainability issues and the spatial classification of sensitive regions in Europe
}

Oliver Dilly $^{1}$, Marguerite Camilleri ${ }^{7}$, Carola Dörrie ${ }^{1}$, Saviour Formosa ${ }^{7}$, Gabrielle Galea ${ }^{7}$, Dionys Hallenbarter ${ }^{3}$, Hubert Hasenauer ${ }^{5}$, Zuzana Imrichová $^{4}$, Renata Korzeniowska-Pucułek ${ }^{2}$, Monika Kowalik², Piotr Koza ${ }^{2}$, Norbert Kräuchi ${ }^{3}$, Ain Kull ${ }^{6}$, Artur Łopatka ${ }^{2}$, Ülo Mander ${ }^{6}$, Stefano Mon$\mathrm{cada}^{7}$, Tonu Oja ${ }^{6}$, Rafal Pudełko ${ }^{2}$, Friedrich Putzhuber ${ }^{5}$, Christian Roga ${ }^{1}$, Bernd Uwe Schneider ${ }^{1}$, Gregorz Siebielec ${ }^{2}$, Tomasz Stuczyński ${ }^{2}$, Reinhard F. Hüttl ${ }^{1}$

(1) Chair of Soil Protection and Recultivation, Brandenburg University of Technology, Cottbus, Germany

(2) Institute of Soil Science and Plant Cultivation, Pulawy, Poland

(3) Swiss Federal Research Institute for Forest, Snow and Landscape Research, Birmensdorf, Switzerland

(4) Institute of Landscape Ecology, Slovak Academy of Sciences, Slovakia

(5) University of Natural Resources and Applied Live Sciences Vienna, Austria

(6) Institute of Geography, University of Tartu, Estonia

(7) Malta Environment and Planning Authority, Malta

\section{Abstract}

Cross-cutting environmental, social and economic changes may have harsh impacts on sensitive regions. To address sustainability issues by governmental policy measures properly, the geographical delineation of sensitive 
regions is essential. With reference to the European impact assessment guidelines from 2005, sensitive regions were identified by using environmental, social and economic data and by applying cluster analysis, United Nation Environmental Policy priorities and expert knowledge. On a regionalised 'Nomenclature of Territorial Units for Statistics' (NUTS) level and for pre-defined sensitive region types (post-industrial zones, mountains, coasts and islands) $31 \%$ of the European area was identified as sensitive. However, the delineation mainly referred to social and economic issues since the regional data bases on environmental indicators are limited and do not allow the separation of medium-term vital classes of sensitive regions. Overall, the sensitive regions showed indicator values differing from the EU- 25 average.

\section{Keywords}

Coasts, European policy, impact assessment, islands, mountains, postindustrial zone, sensitive regions, sustainability impact assessment

\section{Introduction}

The European Union consists of 27 member states in 2007 and covers with 4.2 billion $\mathrm{km}^{2}$ about $40 \%$ of the European continent. Each country of the European Union has its specific history and culture and national governments range from centralised to federalist regimes. The physiographic European Union includes gradients from arctic to Mediterranean, maritime to continental climatic factors and altitudes from sea level to mountains of about $4500 \mathrm{~m}$ above sea level. In 2004, the population density was 118 people per $\mathrm{km}^{2}$ in the European Union (European Commission 2004) compared with 96 people per $\mathrm{km}^{2}$ in the entire European continent and 30 people per $\mathrm{km}^{2}$ in the U.S.A. The uses of land for agriculture, forestry, nature conservation, tourism, energy and transport compete for limited natural resources and strongly influence the environmental, social and economic conditions. These land use types are addressed in the EU Integrated Project 'Sustainability Impact Assessment: Tools for Environmental, Social and Economic Effects of Multifunctional Land Use in European Regions - acronym SENSOR'.

Impact Assessment is now a requirement for EC policy initiatives (Tscherning et al., 2008), and the European Commission published impact assessment guidelines in 2005 (CEC 2005). The guidelines separated five key analytical steps: (1) Identify the problem, (2) Define the objectives, (3) 
Develop main policy options, (4) Analyse their impacts, (5) Compare the options and (6) Outline policy monitoring and evaluation. SENSOR covers steps 4 to 5 . The impact assessment guidelines identified 11 economic (ECON), 9 social (SOC) and 12 environmental (ENV) "impacts", and this analysis has formed the basis for indicator selection within SENSOR (Frederiksen and Kristensen, 2008).

To carry out impact assessment of policy options at European level, regional knowledge is essential. The Nomenclature of Territorial Units for Statistics (NUTS) is a standard for referencing the administrative division of countries for statistical purposes. The standard was developed for the European Union, and thus only covers the member states of the EU in detail. NUTS0 refers to the entire country, NUTS1 level to the next subdivision of states or group of states and NUTS2 and NUTS3 to regions, provinces and counties. SENSOR focuses on a combination of NUTS2 and NUTS3 levels, here called NUTSx level, in order to identify regional scale in addressing both policy options and key issues. Renetzeder at al. (2008) has distinguished 581 NUTSx cells for the EU-27 based on the reference grid of EEA and the European Geo-Portal INSPIRE standards (JRC 2007).

The policy makers at the European Commission need to identify, through Impact Assessment, if there are regions in the member states where policy measures might have unintended and unsustainable consequences, as a result of local conditions. Those regions can be defined as "sensitive". They will differ from regular European NUTSx cells due to their vulnerability regarding environmental, social and economic sustainability issues. For example policy cases to increase the share of bio-energy, to stimulate the preservation of bio-diversity and to strengthen the common agricultural policy may induce cross-cutting conflicts. Such potentially sensitive regions were pre-identified as post-industrial zones, mountains, coasts and islands in Europe, and part of SENSOR's work was to identify these geographically and then arrange them into categories or types, based on specific sensitivities. Special attention was given to new member states of the EU. SENSOR works at EU-27 + 3, to include Iceland, Norway and Switzerland.

The objective of this paper is to summarise the methodology for the analysis of sensitive European regions based on (i) the pre-definition of sensitive region type, (ii) the analysis of free data-bases on sustainability issues and (iii) the application of the European impact assessment guidelines. 


\section{Materials and Methods}

\section{Steps for location and key issue identification}

The generation of the overview of sensitive regions followed 10 steps:

1. Geographical identification of Europe's potentially sensitive postindustrial zones, mountains, coasts and islands, preferentially at the SENSOR NUTSx (here between NUTS2 and NUT3) spatial level,

2. Literature review to identify sustainability issues and data sources, e.g. CORINE land cover (CLC), EUROSTAT and EEA reports,

3. Assessment of secondary data availability and the evaluation of the necessity of collecting primary data,

4. Data collection on key issues in sensitive areas, based on the impact issues identified by the European Impact Assessment Guidelines,

5. Consultation with relevant stakeholders with regard to their view on sustainability issues in sensitive regions throughout Europe,

6. Simple web-based questionnaire to collect qualitative and (semi)quantitative assessment data on key sustainability issues,

7. Statistical analysis and clustering of sensitive regions based on available indicators to create classes of post-industrial zones, mountainous regions, coastal areas and islands with similar environmental, social and economic characteristics,

8. Generation and interpretation of maps with key issues of sensitive areas,

9. Drafting of four sub-survey reports, and compilation into a final report for the 4 sensitive areas types in SENSOR,

10. Integrated and comparative analysis of key sustainability issues across sensitive area types and against a standard, e.g. European average.

\section{Post-industrial zones}

The spatial density of industrial sites within a single NUTSx cell for EU27 based on the CLC 2000 land cover layer was used to identify postindustrial regions. Three classes of industrial sites were separated: (1) combined industrial and commercial sites, (2) dump sites and (3) mineral extraction sites. 
Proxy identification of post-industrial sites was extracted from CLC 2000 using a $5 \times 5 \mathrm{~km}$ moving window. Extraction of post-industrial areas from industrial and commercial classes was based on the assumption that historical sites were often surrounded by dump and excavation sites. In fact, industrial activities until the 1970's generated large amounts of wastes which resulted in a relatively large number of dump sites scattered within industrial zones. Technically, each 100 x $100 \mathrm{~m}$ pixel of commercial/industrial class was classified as post-industrial if accompanied by at least one pixel of dump site or mineral extraction class, within the $5 \times 5$ $\mathrm{km}$ window. Finally, delineated post-industrial objects were combined with dump sites and mineral extraction sites into 'post-industrial sites' and expressed as percent of the total area of each NUTSx cell for the EU-25. NUTSx regions with at least $0.3 \%$ post-industrial sites in the total territory were defined as post-industrial.

Data from EUROSTAT were grouped into environmental, social and economic categories. This process provided complete data sets for about 20 independent indicators at NUTS2/3 level. Biophysical conditions such as length of vegetation period, precipitation, and average temperatures were obtained from the Intergovernmental Panel on Climate Change (IPCC).

Emission data were obtained from the European Pollutant Emission Register (EPER). The database contains facilities responsible for $90 \%$ of the emissions in Europe. The database is divided into contaminant (metals, organic compounds and gaseous compounds) and activity categories (e.g. smelting, refineries, combustions, etc.). The database is limited to EU-15 countries. Emissions generated by all facilities within a region were summed and expressed in tonnes per $\mathrm{km}^{2}$ as total metal, organic and gaseous emission from a region. Dump-site density was calculated for each land use class based on the CLC 2002 and expressed as area of these sites per land use class area.

Finally, a questionnaire was developed to collect additional expert knowledge on sustainability issues in post-industrial regions. Issues addressed in this questionnaire were based on existing reports and EEA data, e.g. from the Clarinet and Caracas studies. A web based tool was prepared to conduct the survey among representatives of local and regional administrations, the research community, NGOs and industry. The interactive ARC IMS server gave and will give detailed survey results on postindustrial sites at the regional and the local level.

Cluster analysis was performed to recognize relatively homogenous groups of regions with similar environmental, socio-economic, agricultural and geographical profiles within the EU-25. Cluster analysis was performed by K-means for NUTS-2/3 EUROSTAT data for 2001 or 2002 
across the EU-25. The variables in the cluster analysis were selected to cover key social, environmental and economic issues and to ensure the distinction between classes of post-industrial zones. Correlation analysis between preliminary sets of input variables was performed to exclude less important variables which were inter-correlated with key indicators. Variables used to distinguish classes were (1) Density of post-industrial sites (\% of total area), (2) Length of vegetative period (days), (3) Mean precipitation in vegetative period IV-X (mm), (4) Unemployment rate (\%), (5) Gross domestic product (GDP; Euro per inhabitant), (6) Population density (inhabitants per $\mathrm{km}^{2}$ ), (7) Economically active population (\% total population), (8) Crude birth rate (N per 1000 inhabitants), (9) Crude death rate (N per 1000 inhabitants) and (10) Employment in industry (\% economically active population).

Land use change analysis was based on the CLC layer of changes obtained from EEA - this was the 2005 version of revised data characterizing land use conversions between 1990 and 2000. The CLC database provides information on land use types grouped into artificial areas, agricultural areas, forests and semi-natural areas, wetlands and water bodies. This is the first level of classification; it is further sub-divided into two sub-levels. One-way land use transitions and net transitions between classes were considered, and trend analysis was performed to assess changes in population density, GDP, natural population growth and employment structure within these homogenous areas throughout Europe. The timeframe for this analysis was dependent on available statistics in EUROSTAT database.

The analysis of relationships was performed using Statistica 6.0 software. Pearson's correlation coefficients were calculated to evaluate the significance of linear relationships between land use changes and biophysical and socio-economic variables. Stepwise regression models were generated to find indicators which explain trends in land use transition between various land cover classes. Identification of sensitive regions was based on comparison of key socio-economic and environmental indicators between types, and in relation to the EU-25 average.

\section{Mountains}

There are several recognised definitions of mountain areas that have been systematically applied. We have adopted the definition according to Nordregio (2004) in which mountains are identified by a combination of altitude above sea level and roughness of the terrain (Table 1). 
Table 1. Identification of European mountains using the criteria 'altitude' and 'slope' according to Nordregio (2004)

\begin{tabular}{ll}
\hline Class [elevation in $\mathrm{m}]$ & Additional criteria \\
\hline 2500 & --- \\
$1500-2499$ & $>2^{\circ}$ slope within $3 \mathrm{~km}$ radius \\
$1000-1499$ & $>5^{\circ}$ slope within $3 \mathrm{~km}$ radius and $/$ or \\
& local elevation range $>300 \mathrm{~m}$ within $7 \mathrm{~km}$ radius \\
$300-1499$ & local elevation range $>300 \mathrm{~m}$ within $7 \mathrm{~km}$ radius \\
$0-299$ & standard deviation $>50 \mathrm{~m}$ for cardinal points \\
\hline
\end{tabular}

The sensitivity of mountain areas is classified according to UNEP criteria and priority areas for Structural Fund Objectives (Council Regulation, 1999). It is a classification by cross-referencing natural factors with socioeconomic indicators (Table 2). The council regulation aims to reduce disparities in development and promote economic and social cohesion in the EU. The effectiveness of the Community's structural assistance is improved by concentrating the assistance, and simplifying its allocation by reducing the number of priority objectives.

Structural interventions of the Commission comprise expenditures for objectives 1 to 3 . The 3 priorities of the Structural Funds are:

(Objective 1) Promoting the development and structural adjustment of the regions whose development is lagging behind. All these regions have a number of economic signals or indicators 'in red'. They indicate low level of investment, a higher than average unemployment rate, lack of services for businesses and individuals, poor basic infrastructure.

(Objective 2) Revitalizing regions with structural difficulties, whether industrial, rural, urban or fishery-dependent. Such areas are faced with socio-economic difficulties that are often the cause of high unemployment though situated in regions whose development level is close to the Community average. These include: the evolution of industrial or service sectors; a decline in traditional activities in rural areas; a crisis situation in urban areas; difficulties affecting fisheries activity.

(Objective 3) Supporting the adaptation and modernization of policies and systems of education, training and employment. 
Table 2. Type-classification of mountains as defined by UNEP criteria for mountain areas and priority areas for Structural Fund Objectives ${ }^{1}$

\begin{tabular}{|c|c|c|}
\hline & Objective 1 & Not eligible \\
\hline $\begin{array}{l}\text { Areas where altitude } \\
\text { creates very difficult } \\
\text { climatic conditions } \\
\text { (minimum altitude } \\
\text { between } 600 \text { and } \\
800 \mathrm{~m} \text { ) }\end{array}$ & $\begin{array}{l}\text { High mountain ranges High mountain } \\
\text { in Spain, in southern ranges in the Alps } \\
\text { Italy (including Sicily)(Austria, Switzer- } \\
\text { and in Greece (includ- land, France and It- } \\
\text { ing Crete), Bulgaria, aly), Andorra, Spain } \\
\text { Montenegro, Romania and southern Italy } \\
\text { and Norway }\end{array}$ & $\begin{array}{l}\text { Certain areas in } \\
\text { the Alps of Aus- } \\
\text { tria, Switzerland } \\
\text { and Italy }\end{array}$ \\
\hline
\end{tabular}

Areas at a lower alti-Other mountain areas Other mountain ar- Certain areas in tude and/or with a in Spain, Portugal, eas in Austria, Swit- Austria, Gersteep average slope Corsica, southern Italy zerland, Germany, many, Switzer(usually more than (including Sicily), France, Italy, Spain land, Lichten$20 \%$ )

Greece, Bosniaand Norway stein and Italy

Herzegovina, Serbia, Macedonia, Romania, Poland, Czech Republic, Slovenia, Hungary and Norway

Other areas north of Mountain areas in the 62nd parallel and northern Norway certain adjacent areas

${ }^{1}$ Priority areas for Structural Fund Objectives (Council Regulation, 1999)

\section{Coasts}

The analysis was started based on NUTSx regions having a shoreline. In addition, those NUTSx regions, located not more than $10 \mathrm{~km}$ from the shoreline and having access to the sea via a river (Antwerpen, OostVlaanderen, Comunidad Foral de Navarra) were included.

Data and indicator values were taken for NUTS2 level from EUROSTAT and for NUTS3 level from national statistics. In addition, maps of CLC 1990 and CLC 2000 were used since changes in CLC may 
indicate endangered regions that may partly be sensitive. CLC biotope layers were also analysed. Information on environmental sensitivity of coastal zones of the 2 European R\&D projects LACOAST and EUROSION in the $10 \mathrm{~km}$ strip along almost the whole coast of EU was also used. The data available at the EEA site (http://www.eea.eu.int/main_html) forms the background for analysis of changes after 1990. Human Development Indicators were used from the UNDP (http://hdr.undp.org/statistics/data/).

The sensitivity analysis of coastal areas was done by combining indicators. Data available for NUTSx cells was used preferentially. When NUTS3 data were not available, NUTS2 data were considered. The indicator values were calculated for all NUTSx cells having a coastal border. Maps were produced employing ArcGIS 9.1 using the ETRS89 - Lambert Azimuthal Equal Area projection.

Conflicts between the major factors of nature conservation, development, restoration, traditional economic use and natural hazards were considered in the analysis.

Similarly to the post-industrial zones, clustering using the k-means algorithm and Statistica 7 was done to classify environmental, social and economic issues and their combinations. To determine clusters of similar NUTSx areas two procedures of cluster analysis were employed using indicators characterising different aspects of sustainability. Cluster analysis was done with 187 NUTSx cells. Monaco were not included since data were not available.

\section{Islands}

The basis of this calculation is the EuroGeographic NUTS0 layer, which excludes certain smaller islands. In addition, the map does not include any 'overseas countries and territories' belonging to EU-27 + 3 nor the French Overseas Departments. Since the Norwegian archipelago of Svalbard had not been included in the NUTS0 map it was added to the list of EU-27 + 3 islands.

Due to the lack of existing studies the methodological approach utilised to identify key sustainability issues across European islands was to select a representative sample of study islands and carry out expert interviews identifying key issues for each study island. A set of 28 representative islands and archipelagos was selected for detailed investigation, based on the 1994 'Portrait of the Islands' study (CEC 1994), which however only covered EU-12. The states of Malta and Cyprus were included since these small island states experience island sustainability issues to an even higher degree than other islands due to lack of support, particularly economic 
support, from a 'mainland'. The set of 28 study islands was drawn up on the basis of the following criteria: (1) For each of the EU-25 countries that have islands, at least one major island or island group was included; (2) The major (in terms of population and size, and political importance such as a high degree of political autonomy) European islands or island groups were included (e.g. Sicily and the Aegean Islands); (3) A selection of both large islands and archipelagos was included (e.g. the Balearic and the Aegean Islands as well as larger islands such as Sardinia and Crete); (4) Islands from both northern and southern Europe were included, as well as those in the Atlantic, in order to ensure a balanced geographical distribution of islands. (5) Islands that are close to the mainland (such as the Tuscan archipelago), as well as ones far from the mainland (such as the Shetland Islands and Pantelleria).

Experts in the study islands were identified through the literature and specialised networks such as the United Nations partnership SUSTIS, the (European) Islands Commission, the Global Islands Network, and the Eurisles project. The questions concerned sustainability issues and indicators, the influence of existing or planned EU polices, and how the EU might best (and least) help the islands under discussion to promote sustainability. A total of 26 experts were interviewed, some representing more than one island.

A list of 143 indicators based on the standard SENSOR list of indicators and on the expert interviews was made. The list was reduced to a final one of 16 indicators, on the basis of four criteria: (1) Is the indicator one of those adopted for SENSOR's overview (Frederiksen and Kristensen, 2008)? (2) How closely does this indicator describe the island's sustainability issue(s)? (3) Are data available for this indicator? (4) Has this indicator an accepted EEA, IRENA or other internationally recognized methodology. The next step was to quantify the indicators. However, considerable difficulties were encountered here as comparable statistics across the islands (Planistat, 2002 and Eurisles, 2002) were not available. The decision was then taken to use comparable data even if the coverage of the data was smaller. A spatial dataset based on these sustainability indicators was developed and used to organize the set of islands into distinct geographical classes. Cluster analysis was performed by K-means and correlation analysis between input variables was performed to exclude those less important variables that were intercorrelated with key indicators. 


\section{Results and Discussion}

\section{Post-industrial zones}

The density of post-industrial areas was below $0.3 \%$ of their surface area in 306 NUTSx cells which corresponded to $65 \%$ of the EU-25 NUTSx cells, and 167 NUTSx cells showing a density of post-industrial areas above $0.3 \%$ were classified as post-industrial regions. These cells cover $25 \%$ of the territory and $50 \%$ of the population of EU-25. The threshold value of $0.3 \%$ is consistent with the value of 0.2 to $0.4 \%$ used in studies for brownfields in western countries (Grimski \& Ferber, 2001).

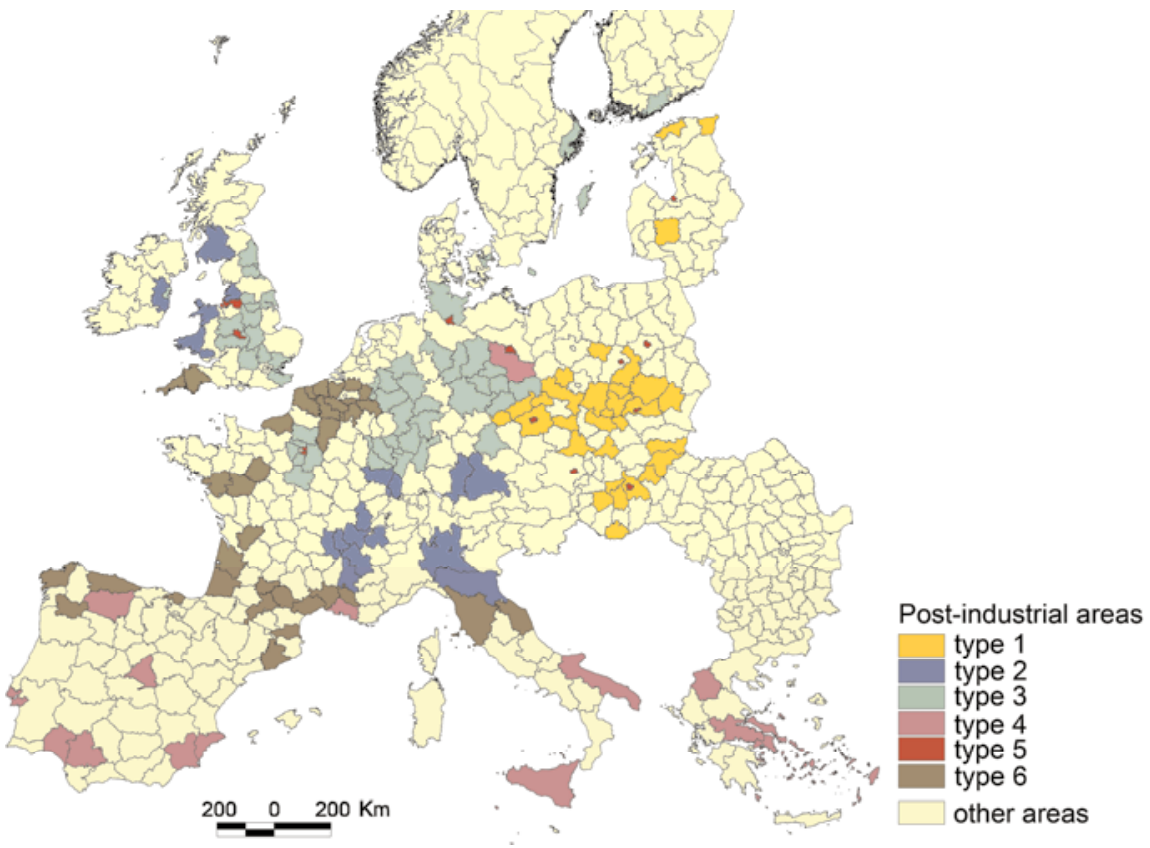

Fig.1. Types of post-industrial zones at NUTSx level across EU-25

The 167 post-industrial NUTSx cells were separated into the following 6 types (Figure 1) based on consistent EUROSTAT data: (Type 1) Eastern transitional industrial, socially and economically weak, (Type 2) Western, economically and socially strong (medium density of post-industrial sites), (Type 3) Western, economically and socially strong (high density of postindustrial sites), (Type 4) Southern, socially and economically weak, (Type 5) Urban, and (Type 6) Western socially weak. Based on the comparison of indicators, Type 1 and Type 4 are most sensitive. The EU coun- 
tries Bulgaria and Romania were not included in the post-industrial type classification as they were candidate countries before 2007. However, all post-industrial regions of these two countries were sensitive as their GDP was half the GDP of Eastern EU post-industrial units.

More in detail, Type 1 covers $4.5 \%$ of total EU-25 area comprising 31 NUTSx cells, mostly Czech, Hungarian, and Polish regions and single regions from Slovakia, Lithuania and Estonia. These regions are characterised by high unemployment rates, decreasing population and lowest population densities. The mean Gross Domestic Product (GDP) is dramatically lower than for other types and about $25 \%$ of the overall EU-25 average. The relative GDP growth is relatively high with $9.5 \%$ but the real difference to other groups is increasing.

Type 4 is characterised by a high unemployment rate and a low share of economically active population., and covers $4.2 \%$ of the total EU-25 area. It is comprised of 15 NUTSx cells located in the southern part of Europe, mostly Spanish and Greek regions and single regions in Italy, France, Portugal and Germany. There is a marked difference between unemployment rates of males and females: $10.5 \%$ and $21.7 \%$ respectively. The unemployment rate of young people is $32.6 \%$.

Ten variables were selected as indicators [with respective impact issues according to COM 2005 in brackets] of sensitivity of post-industrial regions from available EUROSTAT indicators: GDP [ECON7, ECON11], Unemployment rate [SOC1], Unemployment under 25 [SOC1], Female unemployment [SOC3], Population density decline [SOC+], Negative natural population growth $[\mathrm{SOC}+]$, Low share of active population [SOC1], Gaseous emissions [ENV1], Metal emissions [ENV11], Organic compounds emissions [ENV11], Dump sites density [ENV8] and landscape biodiversity [ENV6].

\section{Mountains}

Mountains occur in almost all countries in Europe. They cover 1,900 thousand $\mathrm{km}^{2}$ and $40.6 \%$ of the total land area with 94.3 million people corresponding to $19.1 \%$ of the total population (EEA, 1999). The mountain distribution varies significantly throughout Europe. They can be isolated, but often stretch to huge mountain massifs over hundreds of kilometres. Mountains are ecologically sensitive, and support important and often rare plant communities. Key issues are (1) tourism and recreation, (2) water reservoir, (3) out-migration and population ageing, (4) natural hazards, (5) transport, (6) global change, (7) natural and cultural heritage and (8) soil degradation. 


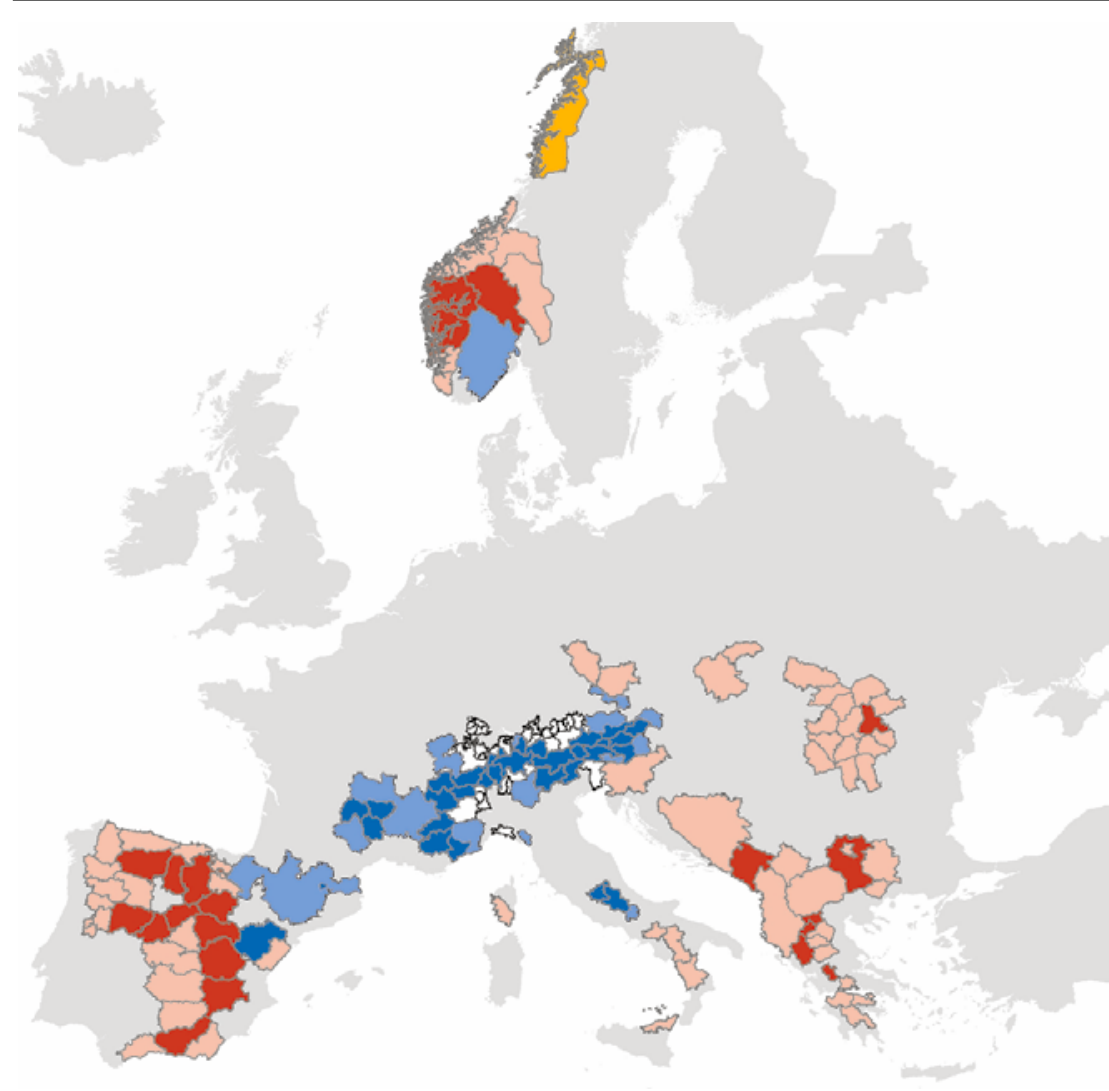

\begin{tabular}{|l|l|l|l|}
\hline & Objective 1 & Objective 2 & Not eligible \\
\hline higher altitude & & & \\
\hline lower altitude & & & \\
\hline north of the 62nd parallel & & & \\
\hline
\end{tabular}

Fig. 2. Sensitive mountain NUTSx cells according to UNEP criteria and priority areas for Structural Fund Objectives by the European Commission

Around 50 NUTSx cells, home of $22 \%$ of the population, are covered by 'objective 1' regions in the period 2000 to 2006 with high mountain ranges in Spain, in southern Italy (including Sicily) and in Greece (including Crete), Bulgaria, Montenegro, Romania and Norway or other mountain areas in Spain, Portugal, Corsica, southern Italy (including Sicily), Greece, Bosnia-Herzegovina, Serbia, Macedonia, Romania, Poland, Czech Repub- 
lic, Slovenia, Hungary and Norway and finally mountain areas in northern Norway (Figure 2). Characteristics for objective 1 regions are low level of investment, a higher than average unemployment rate, lack of services for businesses and individuals and a poor basic infrastructure. The structural funds aim to support economic activities in these regions by providing the basic infrastructure, whilst adapting and raising the level of trained human resources and encouraging investments in businesses. For objective 1 mountain regions, there are important economic sustainability issues.

Objective 2 regions are all areas facing structural difficulties, whether industrial, rural, urban or dependent on fisheries, although the level of development in these regions is close to the Community average. These areas face different socio-economic constraints that are often the source of high unemployment. For objective 2 regions, social and ecological issues may also arise. Therefore, the High Tatras Mountains were chosen as an objective 1 sensitive area case study in comparison with objective 2 ones of Valais and Eisenwurzen.

\section{Coasts}

The geographical identification of coastal NUTSx regions led to 187 cells. The clustering trials on the basis of k-means and NUTSx cells showed high variability between 3 clustering trails. In contrast, the clustering on NUTS2 level separated 6 classes using the following indicators: Population density [n per $\mathrm{km}^{2}$ ], Unemployment 2004 [\%], $\delta$ GDP '95 to '02 [\%], Relative GDP in 2002 [\% of EU-25], GDP per inhabitant ' 95 to 02 [\% of EU-25], GDP per inhabitant, Agriculture in 2003 [\%], Forestry in 2003 [\%], RAMSAR sites [n per cell], RAMSAR sites [n per $\mathrm{km}^{2} 1$ ], Urban population [\%], Ecologically valuable areas [\%], R\&D in 2004 [mEUR], Coastal length $[\mathrm{km}]$, Coastline exposed to erosion $[\mathrm{km}]$.

Six coastal clusters were identified (Figure 3): (1) economically and socially strong; the development rate is moderate but GDP is above EU-25 average; high share of urban population combined with low unemployment; high environmental awareness, (2) stable, relatively slowly developing economy with high share of agricultural activities; high share of rural population and relatively low GDP; which causes also a high rate of unemployment; environmental awareness is marginal, (3) moderately developing economy which is slightly influenced by a high unemployment rate, a high share of urban population; GDP remains slightly below EU-25 average, (4) economically and socially very strong; high share of urban population combined with high population density; low unemployment; long coastline; well developed environmental awareness, (5) rapidly grow- 
ing economy combined with relatively high but decreasing unemployment, low but increasing income; R\&D investment rate low; low share of arable land and high share of rural population; in spite of moderate coastal length the highest share of coast exposed to coastal erosion; environmental protection has high variability within the classes (from $14 \%$ to $2 \%$ of area for

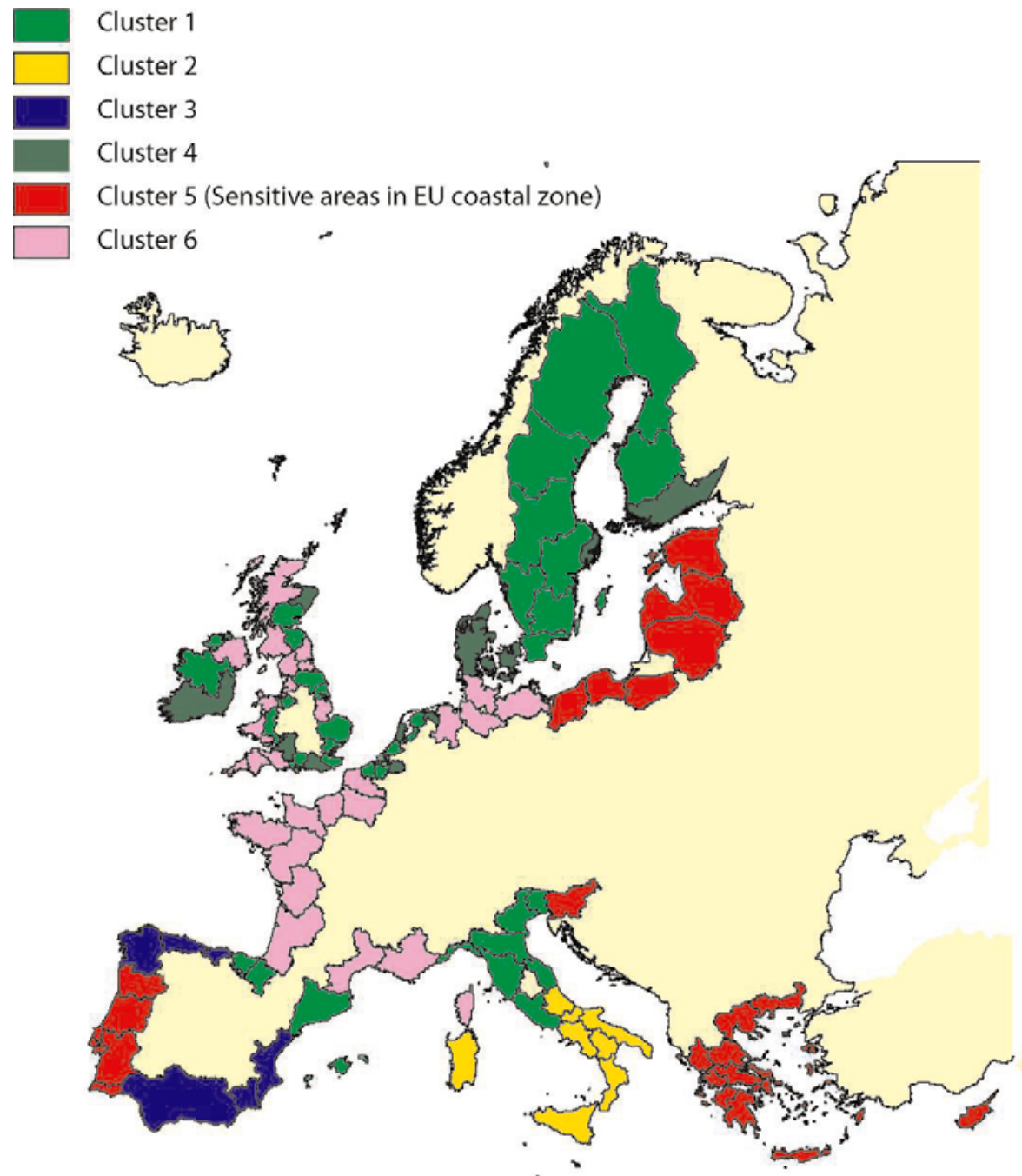

Fig. 3. Classes of European coasts at NUTSं2 level

designated areas); however, in the Baltic Sea coastal zone of this cluster environmental and nature protection issues are of high importance and (6) traditionally strong and stable economy with high share of agricultural ac- 
tivities; population density is high and most of population is living in urban areas; in spite of high living standards, high $\mathrm{R} \& \mathrm{D}$ expenditure is needed to avoid economical stagnation.

Class 5 was considered as most sensitive since it showed rapid changes in socio-economic issues and conflicts between intense development for tourism development and nature conservation. Class 5 encompassed 23 NUTS2 cells and included 5 islands.

\section{Islands}

A total of 4,966 islands were identified from the EU NUTS-0 map, occupying $265500 \mathrm{~km}^{2}$ or $5.6 \%$ of the land area of EU-27 + 3. The Norwegian archipelago of Svalbard was added to this list. The Figures including the 150 Svalbard Islands are 5,116 European islands, occupying a land area of $328021 \mathrm{~km}^{2}$ or $6.8 \%$ of the area of EU27 +3 .

Island regions were found in 136 NUTSx cells, from which 25 NUTSx cells were made up entirely of islands and Corsica and the Canaries consisted of two NUTSx cells. These Islands are: Aland, the Azores, Balearic Islands, Bjornoya, Bornholm, Canary Islands, Channel Islands, Corsica, Crete, Cyprus, Faeroe Islands, Gotland, Iceland, Ionian, Isle of Man, Jan Mayen Islands, Madeira, Malta, North Aegean, Sardinia, Sicily and South Aegean. The rest of the NUTSx units are occupied by islands to varying degrees. For example 63 of these NUTSx regions have less than $1 \%$ island territory; another 38 have less than $10 \%$ island territory; and 10 regions have between $11 \%$ and $36 \%$ island territory.

The dataset from the 26 expert interviews on the 28 study islands identified the following $12 \mathrm{key}$ sustainable development issues, which reflect the islands 'backwardness' issues identified elsewhere (Planistat, 2002; Eurisles, 2002): (1) High population dynamics, (2) Low potential for economic diversification, (3) Negative impact of land development, (4) High pressure on marine water quality, (5) High consumption of freshwater, (6) Waste management challenges due to small size and remoteness, (7) Tourism pressures, (8) Insularity and peripherality, (9) Declining agriculture and fisheries, (10) Degradation of natural resources and loss of biodiversity, (11) High cost and impact of energy use and (12) Low levels of education and training. 


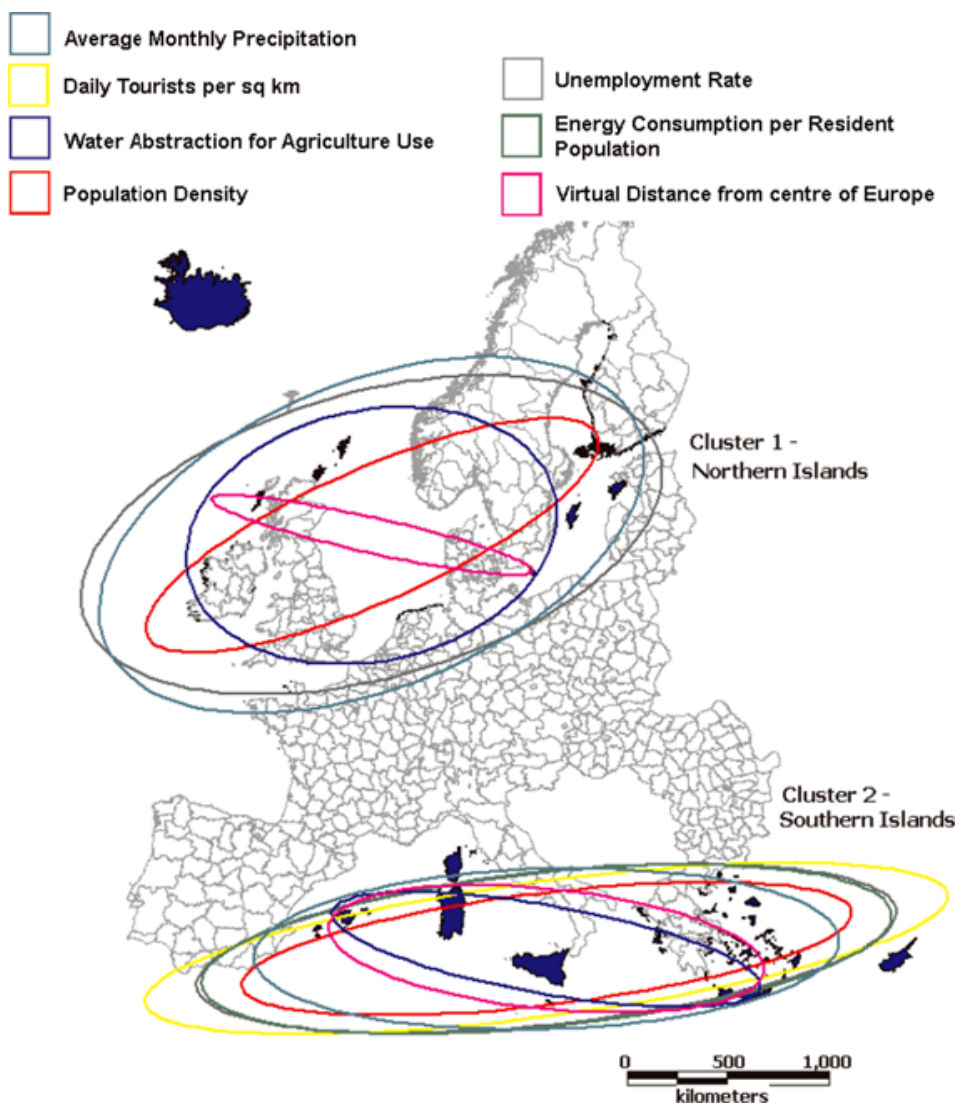

Fig. 4. Classes of islands based on the clustering of sustainability issues of 28 study islands

On the basis of these issues, the following sustainability indicators were identified: (1) Population density, (2) \% of population above 65 years, (3) Employment by sector, (4) Unemployment rate, (5) GDP per capita (EURO/National currency), (6) \% land built up (proxy: \% urban area of total [CLC]), (7) Compliance with Bathing Water Directive, (8) Water abstraction rate (ground and surface) (Proxy: ag. water abstraction rate [IRENA]), (9) Precipitation rate, (10) Municipal waste generation per capita, (11) Daily tourists per square kilometre, (12) Virtual distance from centre of Europe (Eurisles study), (13) \% agricultural land use change, (14) $\%$ of land covered by Natura 2000 sites (proxy: \% land with protective designation), (15) Energy consumption per resident population and (16) \% of researchers in relation to active population. 
On the basis of a cluster analysis performed spatially on these variables two classes were identified (Figure 4): Northern Islands and Southern Islands. The island Malta, which has a central position in the Southern Islands Cluster, is suggested as sensitive area case study for the European islands. Results show that another impact issue "insularity and vulnerability" should be added to the list of sustainability impact issues elaborated by the EU Commission.

\section{Overview of key sustainability issues in sensitive regions in Europe}

A first joint overview identified more than $50 \%$ of the NUTSx cells of the EU-25 as sensitive. This was because mountains and coasts were geographically important in more than 100 NUTSx regions each. More specific classes in each of the 4 sensitive region types were identified mainly on the basis of socio-economic data from EUROSTAT. Additional environmental indicators were acquired to be consistent with the three pillars of the sustainability impact assessment. This more specific classification helped us to identify high priority cells with reference to key sustainability issues and UNEP standards. The overview here defined about $31 \%$ of the area as sensitive. There is a minimal overlap between 2 or more sensitive area types, not exceeding $2 \%$ of total area.

Sensitive regions frequently showed indicator values differing from the EU-25 average. This is illustrated for the 8 chosen indicators relating to sustainability issues and land use (Figure 5). For example, the percentage of agricultural areas was substantially smaller at coasts and in postindustrial zones with $9 \%$ and $24 \%$ respectively, in contrast to $52 \%$ for the EU-25 overall. This indicates the competition between agricultural land use and other land use types and land use functions (Perez-Soba et al., 2008). Coasts showed both many small and many large farms in comparison to the EU-25. For mountains, low population growth is typical. In contrast, population growth was high on islands. For islands, the 8 selected indicators were closer to the EU average. The visualisation in Figure 5 can be used to reflect the conditions in the selective region type and to discuss the case specific threshold and limits (Bertrand et al. 2008; Haynes-Young and Potschin 2008). Figure 5 emphasises values exceeding the EU average by more than $30 \%$ and being outside the grey circle which are non-typical and may thus be discussed as critical. The indicator values inside the grey circle can be considered as non-critical. 
The data availability relating to environmental issues was poor at NUTSx level. Furthermore, islands issues may not be representative as available statistics often concern major NUTSx regions of which islands represent a minor part. In addition, extreme indicator dynamics in islands are frequently not well reflected at the NUTSx level.
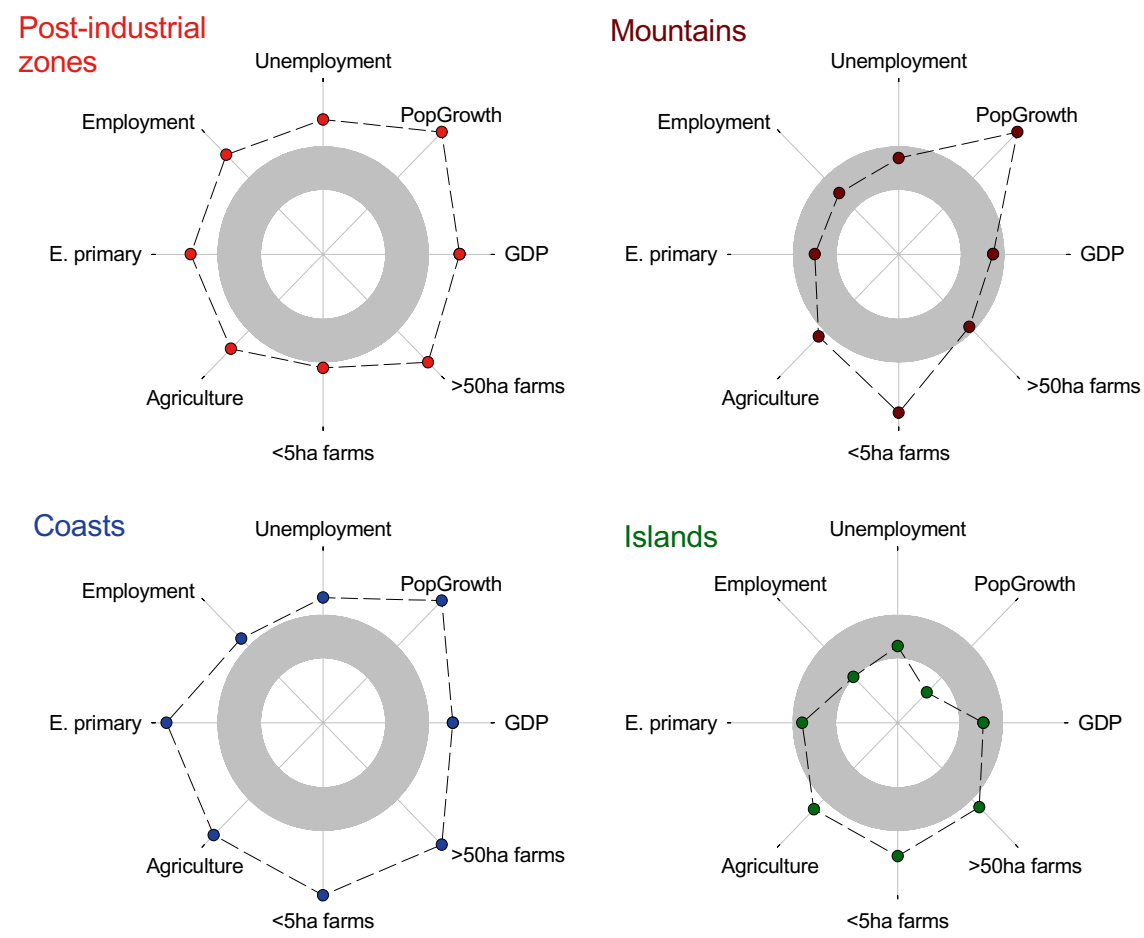

Fig. 5. Eight indicators in the 4 sensitive area types relative to the EU-25 average. The grey circle represents the EU-25 average $(100 \%) \pm 30 \%$. Dots outside the circle represent the visualisation of a critical status compared to dots on and inside the circle. Abbreviations: PopGrowth - Population growth; $>50$ ha farms - percentage of farms larger than $50 \mathrm{ha} ;<5$ ha farms - percentage of farms smaller than 5 ha; ; Agriculture - agricultural area in \%; E. primary - Employment in the primary sector

Information from sensitive regions is highly relevant for the development of 'Sustainability Impact Assessment Tools' (SIAT; Sieber et al., 2008). The SIAT is designed for ex-ante impact assessment of land-use relevant policies and integrates about 60 indicators designed for scenarios of the policy cases, Bioenergy, Common Agricultural Policy, Biodiversity, Forest, Transportation and Tourism (Kuhlman et al., 2008). Out of this Euro- 
pean wide overview 3 out of 7 sensitive area case studies were also chosen as regular test regions, to test the analysis of the NUTS X cluster regions (Figure 6). These 3 regions are Silesia (Poland), the Estonian costal zone and Malta. The other 4 case studies are Lusatia (Germany), Eisenwurzen (Austria), High Tatras (Slovakia) and Valais (Switzerland). From the 7 case studies, information (data) was acquired, harmonised and preprocessed to enable the testing of the SIAT on both, regularly managed areas and sensitively managed areas. Based on this strategy land use impact on average and on more extreme but still typical conditions will become evident. The clear advantage of this approach is that it allows policy makers a relevant judgement on land use practices on a wider range of existing site conditions.

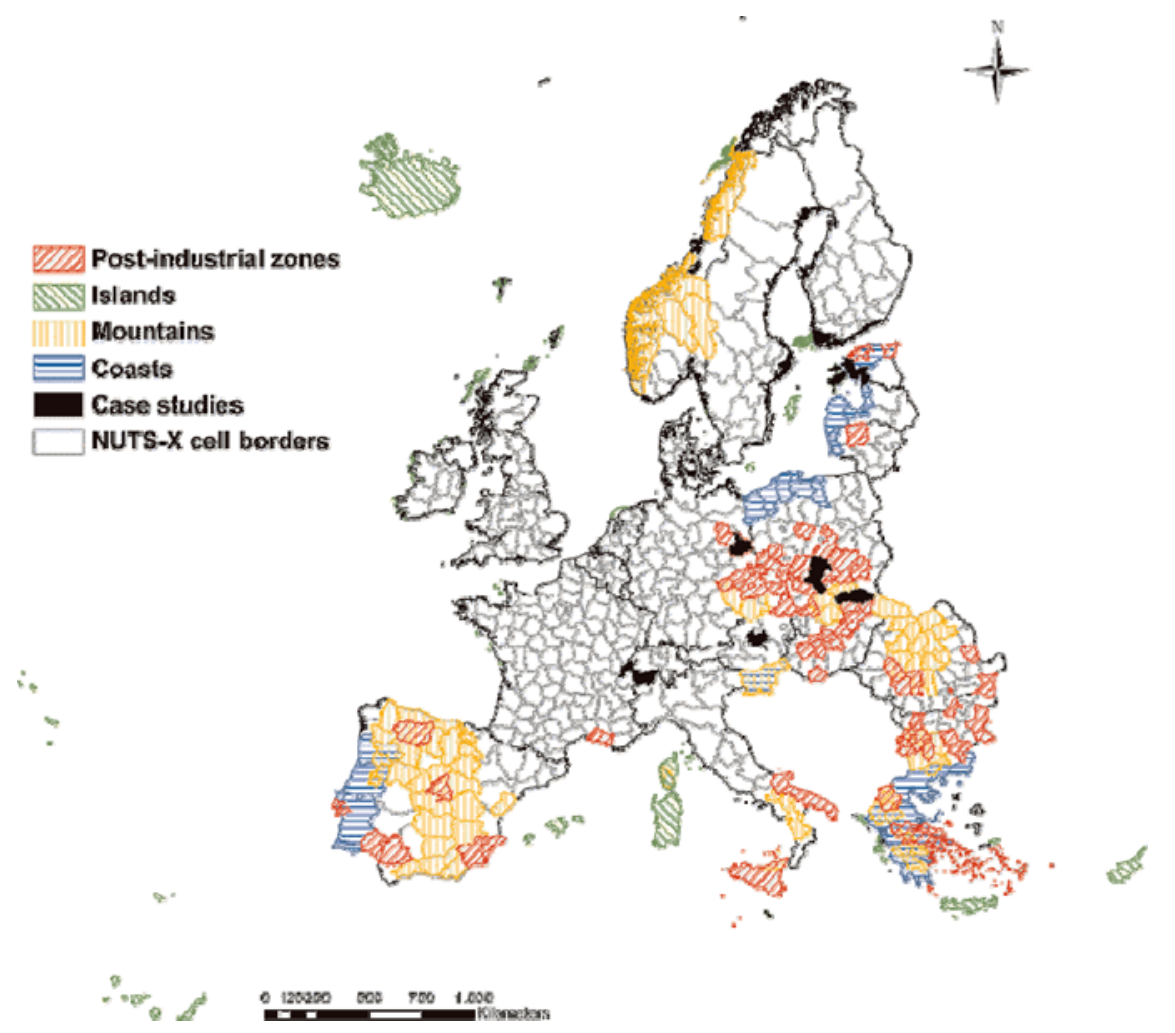

Fig. 6. Geographical location of sensitive regions and sensitive area case studies in Europe

From the social perspective, coasts and post-industrial zones face significantly higher unemployment rates compared to regular or average EU-25 
regions (Figure 5). The unemployment rate here particularly marginalizes females reaching $16 \%$ of the active population. Negative population growth was associated with high unemployment in post-industrial zones and coasts, where it was substantially lower than in the EU-25. The economic performance measured by GDP per inhabitant was less than $50 \%$ of the EU-25 in coasts and post-industrial zones. All 8 indicator values in 0 exceeded the EU-25 average in the post-industrial zones and coasts.

The geographic overview of sensitive regions in Figure 6 shows that in area terms, mountain sensitive regions were the most important with $14 \%$ of the total EU area, whereas the contribution of post industrial, islands and coastal regions was $8 \%, 6.8 \%$ and $6 \%$ respectively.

In contrast to this approach with paying special attention to pre-defined sensitive regions, the clustering of the entire European 581 NUTSx cells in the Spatial Regional Reference Framework (SRRF, Renetzeder et al., 2008) separated approximately 30 clusters by using biophysical, socioeconomic and administrative parameters. However, the SRRF clusters may not match to the separated sensitive classes and thus policy measures to be applied in sensitive regions may refer to other regions than to be applied to SRRF classes.
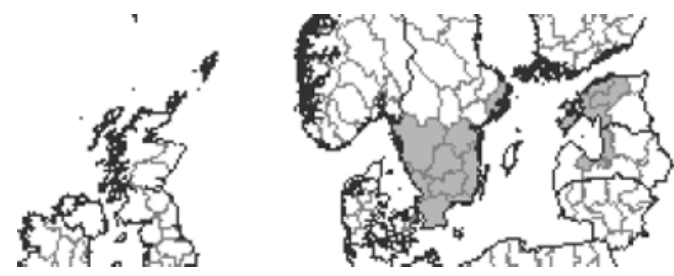

Fig. 7. Cluster 2600 NEMFOR (Renetzeder et al. 2008) includes Nemoral regions in Sweden Estonia, Finland, Latvia. Large parts are lowlands $(>80 \%)$ or hills $(<20 \%)$, parent material is formed by different sediments. The population density is varying between 103 and 165 inhab./km2, GDP index between 66 and 104 . Around $80 \%$ of the land is covered by forests

\section{Conclusions}

1. Based on most consistent EUROSTAT and some complementary data related to sustainability issues and using cluster analysis, UNEP priorities and expert knowledge, sensitive post-industrial zones, mountains, coasts and islands were identified across Europe at NUTSx scale. Various dis-aggregation and aggregation procedures were necessary in this bottom-up approach. Identified key sustainability issues 
have been consolidated into one list of sustainability issues for all $\mathrm{EU} 27+3$ sensitive regions.

2. Sensitive regions were located in the southern, western and eastern EU27 + 3 area and face specific environmental, social and economic problems such as low GDP, low natural population growth, high unemployment rate, small farm sizes and high pressure on valuable biotopes related to global markets and political change.

3. Forty-six post-industrial NUTSx cells of 581 EU-25 +5 cells were classified as sensitive based on analysis of their socio-economic and environmental profile. Eastern and southern groups of post-industrial regions were defined as sensitive. Sensitivity is mainly driven by high unemployment, low GDP and demographic indicators such as population decline or low share of active population.

4. The sensitive mountains were identified according the objective 1 of the UNEP approach. About 50 NUTSx cells were referred to as sensitive across Europe.

5. At NUTS2 level, 28 sensitive coastal cells were identified. An analysis was not feasible at NUTSx scale. Main conflicts in these cells are caused by rapidly growing economy combined with relatively high but decreasing unemployment, low but increasing income, a low rate of R\&D investment, and high ecological value of ecosystems under pressure.

6. Island regions were found in 136 NUTSx units, and 24 of these are entirely made up of islands. There was a lack of statistical data on sustainability issues for European islands mainly due to the fact that they are often classified at lower than NUTS2 level..

7. In total, about $31 \%$ of the EU27 +3 area was defined with as sensitive our methodology. There is a minimal overlap between 2 or more sensitive area types, not exceeding $2 \%$ of total area.

8. The delineation was based mainly on social and economic issues since the regional data bases on environmental indicators are limited and did not allow the separation of classes of sensitive regions.

9. The study showed unique patterns of socio-economic and environmental characteristics in the sensitive region types, which differed from regular European regions. Thus land use will change differently in response to EU policies. SIAT should be tested within sensitive regions to assess its robustness in sensitive regions which cover a substantial portion of the European territory. 


\section{References}

Bertrand N, Jones MLM, Hasler B, Omodei-Zorini L, Petit S, Contini C (2008) Thresholds and targets in regional sustainability assessment. In: Helming K, Tabbush P, Perez-Soba M (Eds). Sustainability impact assessment of land use changes. Springer, 405-424

Commission of the European Communities (1994) Portrait of the Islands. EUROSTAT, Directorate General for Regional Policy. Luxembourg: Office for Official Publications

Commission of the European Communities (2004) Portrait of the European Union. Office for Official Publications of the European Communities, Luxemburg

Council Regulation (1999) EC No 1260/99 of 21 June 1999 laying down general provisions on the Structural Funds http://europa.eu/scadplus/leg/en/lvb/160014.htm; date 29-11-2007

http://ec.europa.eu/regional_policy/intro/working4_en.htm; date 29-11-2007

COM (2000) Indicators for the integration of environmental concerns into the common agricultural policy, 20 final (Brussels), 26 pages

COM (2005) Impact assessment guidelines. SEC 791 (Brussels), 48 pages

Carey PD, Preston CD, Hill MO, Usher MB, Wright SM (1995) An environmentally defined biogeographical zonation of Scotland designed to reflect species distributions. Journal of Ecology 83, 833-845

EEA (1999) Environment in the European Union at the turn of the century. Environmental Assessment Report 2, Official Publications of the European Communities, Luxembourg

Eurisles (2002) Off the Coast of Europe: European construction and the problem of the islands. Study undertaken by Eurisles on the initiative of the Islands Commission of CPMR, (Conference of the Peripheral and Maritime Regions), available at www.eurisles.org

Grimski D, Ferber U (2001) Urban brownfields in Europe. Land Contamination and Reclamation 9, 143-148

Frederiksen P, Kristensen P (2008) An indicator framework for analysing sustainability impacts of land use change. In: Helming K, Tabbush P, Perez-Soba M (eds). Sustainability impact assessment of land use changes. Springer,293-304

JRC (2007) http://www.inspire-geoportal.eu; date 29-11-2007

Kuhlman T (2008) Scenarios - driving forces and policies. In: Helming K, Tabbush P, Perez-Soba M (eds). Sustainability impact assessment of land use changes. Springer, 131-157

Nordregio (2004). Mountain areas in Europe, Analysis of mountain areas in EU Member States, acceding and other European countries, Nordregio Final Report 2004:1, Stockholm, 271 pp ISBN 91-89332-35-0 Electronically available at Inforegio

Perez-Soba M, Petit S, Jones L, Bertrand N, Briquel V, Omodei-Zorini L, Contini C, Helming K, Farrington J, Tinacci Mossello M, Wascher D, Kienast F, de Groot R (2008) Land use functions - a multifunctionality approach to assess the impact of land use change on land use sustainability In: Helming K, Tab- 
bush P, Perez-Soba M (eds). Sustainability impact assessment of land use changes. Springer, 375-404

Planistat Europe (2002) Analyse des régions insulaires de l'Union européenne (Survey of insular regions of the EU). Interreg project, DG Regio

Potschin M, Haines-Young R (2008) Making Sustainability Impact Assessments: Limits, Thresholds and the Sustainability Choice Space. In: Helming K, Tabbush P, Perez-Soba M (eds). Sustainability impact assessment of land use changes. Springer,425-450

Renetzeder C, van Eupen M, Mücher CA, Wrbka T (2008) A Spatial Regional Reference Framework for Sustainability Assessment. In: Helming K, Tabbush P, Perez-Soba M (eds). Sustainability impact assessment of land use changes. Springer, 249-268

Sieber S, Müller K, Verweij P, Haraldsson H, Fricke K, Pacini C, Tscherning K, Helming K, Jansson T (2008) Transfer into decision Support: The Sustainability Impact Assessment Tool (SIAT). In: Helming K, Tabbush P, Perez-Soba $\mathrm{M}$ (eds). Sustainability impact assessment of land use changes. Springer, 107128

Tscherning K, König H, Schösser B, Helming K, Sieber S (2008) Ex-ante Impact Assessment (IA) in the European Commission - a classification. In: Helming K, Tabbush P, Perez-Soba M (eds). Sustainability impact assessment of land use changes. Springer, 17-33

Zhou Q, Roson M (2001) Automated rangeland vegetation cover and density estimation using ground digital images and the spectral-contextual classifier. International Journal of Remote Sensing 22, 3457-3470 